\title{
FAMILY COHESION, INTERPERSONAL COMMUNICATION, AND SMARTPHONE ADDICTION: DOES IT AFFECT CHILDREN'S EMOTIONAL DYSREGULATION?
}

\author{
Irfan Fauzi Rachmat ${ }^{1 *}$, Sofia Hartati ${ }^{2}$, Erdawati ${ }^{2}$ \\ ${ }^{1}$ Universitas Muhammadiyah Cirebon, Indonesia \\ ${ }^{2}$ Universitas Negeri Jakarta, Indonesia \\ *e-mail: irfan.fauzi@umc.ac.id
}

\begin{abstract}
Emotional dysregulation in early childhood has shown various early symptoms, such as aggressiveness, anxiety, short attention span, etc. This study aims to determine the effects of family cohesion, interpersonal communication, and smartphone addiction variables on children's emotional dysregulation. The respondents of this study were 338 students' parents from Cirebon City, Indonesia. Data were collected by means of online questionnaires distributed individually to each kindergarten selected using proportionate cluster random sampling. The results of this study show that two variables, namely family cohesion $(p=.031)$ and interpersonal communication $(p=.016)$ have negative direct effects on children's emotional dysregulation. Meanwhile, smartphone addiction $(p=.000)$ directly affects children's emotional dysregulation. From the results, it is assumed that children's emotional dysregulation will decrease when there is a focus on improving the quality of family cohesion and on decreasing the level of smartphone addiction. Besides, the government, schools, and parents should concern about and implement a policy to keep on monitoring children when using smartphones and developing positive and harmonious family cohesion.
\end{abstract}

Keywords: addiction, communication, emotional dysregulation, family cohesion.

\section{KOHESI KELUARGA, KOMUNIKASI INTERPERSONAL, DAN KECANDUAN SMARTPHONE: APAKAH BERPENGARUH TERHADAP DISREGULASI EMOSI ANAK?}

\begin{abstract}
Abstrak: Masalah disregulasi emosi anak usia dini saat ini telah menunjukan berbagai macam gejala awal, seperti anak yang agresif, rasa cemas, fokus rendah, dan lainnya. Penelitian ini bertujuan untuk melihat ukuran pengaruh dari variabel kohesi keluarga, komunikasi interpersonal, dan kecanduan smartphone terhadap disregulasi emosi anak. Responden dalam penelitian ini berjumlah 338 orang tua siswa di Kota Cirebon, Indonesia. Data dikumpulkan melalui kuesioner daring yang di bagikan secara individual kepada setiap TK yang telah di pilih secara proportionate cluster random sampling. Hasil studi penelitian menunjukkan bahwa kohesi keluarga $(p=0,031)$, komunikasi interpersonal $(p=0,016)$ memiliki pengaruh langsung negatif terhadap disregulasi emosi anak. Sedangkan kecanduan smartphone $(p=0,000)$ memiliki pengaruh langsung positif terhadap disregulasi emosi anak. Dari hasil penelitian ini dapat diasumsikan bahwa, disregulasi emosi anak turun apabila perhatian dalam peningkatan kualitas ada pada variabel kohesi keluarga dan penurunan tingkat kecanduan smartphone. Selain itu, pemerintah, sekolah ataupun orang tua perlu membuat kebijakan dan memeberikan perhatian bersama untuk terus memantau penggunaan smartphone pada anak, dan menciptakan kohesi keluarga yang positif dan harmonis.
\end{abstract}

Kata Kunci: kecanduan, komunikasi, disregulasi emosi, kohesi keluarga.

\section{INTRODUCTION}

Early childhood is an individual who is developing rapidly. All aspects of development are in a sensitive period. Every early childhood learns something new, and there will be a fantastic leap in development: the sensitive period, the golden age, or the sensitive period known, especially during early childhood.
However, the sensitive period and the golden ages will be perilous if not adequately prepared. Parents' role as the closest people to their children has a role in making early childhood grow and develop in a positive direction. Parents' challenges and roles are very dominant, apart from the course being influenced by several other factors, such as the environment, 
patterns of communication relationships between parents and children. Conversely, if parents are ignorant and ignore the sensitive period of early childhood, some unwanted problems will arise when they reach adolescence or as an adult.

This problem, for example, is the emergence of various kinds of criminal cases and delinquency that occurred when children or adolescents. As stated by the national commission for child protection on online media portals, children's level of delinquency cases is increasingly worrying. This case and delinquency certainly cannot underestimate. The cases of delinquency and crime that occur will endanger children's future, especially in the modern era.

The Commission on Child Protection notes that criminal cases committed by children continue to increase every year. In 2018, it was around a $26 \%$ increase from last year. They report children as perpetrators of violence. Violence committed is physical and non-physical violence. Then, throughout 2019, children faced the law $(\mathrm{ABDH})$ in Indonesia, namely at least around 2,879 children committed acts of violence, where the age range of the children was 6-14 years old.

The age range 6-14 years is early childhood. There is a difference between early childhood under the Indonesian National Education Law in 2003 and NAECY (National Association of Early Childhood and Youngest). According to the National Education System Law, early childhood is in 0-6 years. Meanwhile, according to NAECY, early childhood is in the age range of $0-8$ years. The violent and criminal behavior mentioned above actually also occurs during the early childhood span, namely the age range of 6-8 years.

As well known, according to Piaget, early childhood is in a concrete pre-operational and operational stage. According to Piaget, in the pre-operational stage, he explained that early childhood does not have perfect maturity at the pre-operational stage. The immature aspect at the pre-operational stage is centration, namely the tendency to focus on one aspect of the situation and ignore others (Papalia, Feldman, Martorell, Morán, Herrera, Salinas, \& Dávila, 2012). Children will focus on one thing and not be able to see problems outside the perspective of others. We can say this centration stage to be selfish, wanting to win alone, and not caring about others is the child's inability to manage their emotions.

Children's inability to manage emotions, or emotional dysregulation, is an issue in children's social and emotional aspects in preschool (Rubinsztein, Gestwicki, Murphy, \& Klionsky, 2007). The occurrence of emotional dysregulation in preschools, such as children who go to kindergarten, early childhood education, or other playgroups, has become a widely researched problem. Such as the slow process of child development in regulating children's behavior at their age, what factors cause problems in this deregulation, and others.

According to Denham, Bassett, \& Wyatt (2010), children who attend preschool or kindergarten explain that children who are not easily angry and their playmates will prefer to look happy. Likewise, the teacher explaining that children who are friendly and easy to work with by teachers prefer teachers because they show positive emotions (Denham et al., 2010). This child's positive emotions show that children are better at regulating their emotions so that their aggression level will be lower when interacting with their peers.

Early childhood, which is not good at regulating their emotions, will raise various child behavior problems. This problem continues when children reach adolescence and adulthood compared to children who have good emotional regulation abilities (Denham et al., 2010; Havighurst, Wilson, Harley, Kehoe, Efron, \& Prior, 2013; Robins \& Rutter, 1990). Aggressive behavior, high levels of hyperactivity, and impatience are emotional dysregulation problems in children in early childhood (Miller, Kiely Gouley, Seifer, Dickstein, \& Shields, 2004).

Some examples of children's emotional dysregulation behavior that arise when preschoolers are screaming, impatient, or unable to wait, like hurting, destroying friends' belongings, destroying their property, hitting, unable to sit quietly, running around, and others (Achenbach, Edelbrock, \& Howell, 1987; Joormann \& Gotlib, 2010; Joormann \& Quinn, 2014). So that today character education for early childhood is prioritized rather than just being smart. Because it does not rule out that in the future, a generation of people will appear filled with intelligent people with a variety of 
knowledge, but not balanced with good moral qualities (Hidayati, Kaloeti, \& Karyono, 2011).

Early childhood who have difficulty with their emotional regulation skills will undoubtedly be difficult for caregivers and parents alike. Parents and caregivers will find it challenging to understand the child's demands. It is difficult to understand, but it will affect parents' stress level while doing parenting (Calkins \& Dedmon, 2000). So this is a challenge for parents to understand the emotional dysregulation of early childhood better because we associate emotional dysregulation with childhood social withdrawal (Coll, Kagan, \& Reznick, 1984).

Social withdrawal in early childhood is also accompanied by common signs of emotional dysregulation, such as isolation or solitude, screaming, lack of eye contact, refusal to talk, like running away from problems, crying, high levels of anxiety (Olatunji, Forsyth, \& Feldner, 2007). Anger and aggression and decreased interpersonal relationship quality (Pond, Kashdan, DeWall, Savostyanova, Lambert, \& Fincham, 2012). It groups these general signs into two categories: emotional dysregulation associated with internalizing behavior and children's externalization (Macklem, 2007).

According to Macklem (2007), it explains that emotional dysregulation associated with internalizing behavior, namely: 1) showing emotions that are too strong for a situation; 2) difficulty calming down when upset; 3) difficulty reducing negative emotions; 4) less able to calm down; 5) difficulty understanding emotional experiences; 6) being avoidant or aggressive when dealing with negative emotions and 7) experiencing more negative emotions. Meanwhile, externalizing behavior is: 1) showing more extreme emotions; 2) difficulty identifying emotional cues; 3) difficulty recognizing their own emotions; 4) focus on the negative; 5) difficulty controlling the attention of others; 6) being impulsive; 7) difficulty reducing their negative emotions, and 8) difficulty calming down when upset.

The various emotional dysregulation of the child is, of course, influenced by various causes. For example, the form of a child's prior experiences with caregivers or parents can cause differences in regulating children's emotions. Parents who respond to signals of children's needs and wants can help children can regulate their emotional systems. A stressful interaction or parenting style can undermine the development of a child's emotional regulation. So that various kinds of parenting strategies must work hard to support a child to have self-control abilities. One way, of course, that parents or caregivers must become outstanding figures or models, not just demanding children (Bronson, 2001).

Another cause is the family environment's role, where a child will expose and learn about the management and development of children's emotional regulation for the first time. Family cohesion must, of course, provide an appropriate level of freedom and boundaries. Family cohesion should provide opportunities for a child to practice self-regulation. Family environments with opportunities to practice social skills without excessive stimulation or frustration help children develop self-regulation skills (Bronson, 2001).

Parents will pay proper attention to children through a positive family environment. Children do not easily find fun through games or games or video shows displayed through digital technology devices. That way, there will be an attachment between parent and child. Children's attachment to their parents can arise from the various interactions they have made, like playing together, joking with each other, or doing fun and other activities.

In fact, in today's modern and alldigital era, parents tend to give less favorable treatment and attention to their children. The form of disturbance that occurs during parents' interaction with children is parents' smartphone devices and the level of children's smartphone use, which is very concerning.

The progress of the times that is happening today has been developing quickly. Of course, this will affect the environment in which children play and learn. The age of the Internet, otherwise known as IoT (Internet of Things), has become necessary and a daily lifestyle known as the industrial revolution 4.0, which emphasizes Artificial Intelligence, Big Data, Robotics, and others. Using digital devices and technological sophistication is used in companies or schools and has entered the family environment.

In the current era of globalization, child development is also influenced by technology and communication tools. It reflects this in the changes in some people who make 
communication and information technology part of their lifestyle. Children are familiar with technology products, such as smartphones, TV, iPods, and the Internet. The availability of various digital technologies is because parents facilitate the environment in providing facilities and infrastructure at home. They are used to surfing in cyberspace, playing games, smartphones, watching YouTube and TV shows, which they hope will be fun toys and places to answer their curiosity (Warisyah, 2015).

The results showed that the duration of children's use of digital technology affects children's difficulty giving up their gadget addiction (Gutiérrez, de Fonseca, \& Rubio, 2016). One reason is that they often see parents interacting with digital technology devices. Early childhood cannot deny that they imitate and are often exposed to digital technology tools. The high interaction between adults and parents with digital technology can affect parents and children's interaction (Kildare \& Middlemiss, 2017). So that in the end, it can cause emotional dysregulation in children.

From the background explanation above, the authors are interested in researching the emotional dysregulation of early childhood in Cirebon City, which is influenced by family cohesion variables, interpersonal communication mediated by the level of early childhood smartphone addiction. This research's object is the level of emotional dysregulation and smartphone addiction in early childhood that occurs in kindergarten children in Cirebon City, aged 4-6 years. Hope to find the best solution in reducing digital technology use for early childhood and providing understanding and efforts to develop early childhood emotional regulation skills.

\section{METHOD}

The research method used in this study using an associative quantitative approach, using SEM (Structural Equation Model) analysis techniques. The data collection process will be given a questionnaire to measure each variable (Sugiyono, 2016). The questionnaire given is an online questionnaire distributed to research subjects selected based on the respondent's characteristics, where the respondent provides answers to the statements given.

Structural Equation Modeling (SEM) is a second-generation multivariate analysis technique for testing complex variable relationships. SEM can test structural models and measurement models, test measurement errors, factor analysis, and hypothesis testing. SEM is a statistical modeling technique that is highly cross-sectional, linear, and general, including factor analysis and regression used to test statistical models as a causal model.

SEM includes the measurement of the covariance matrix structure, also known as "covariance structure analysis." Once the model parameters are estimated, the model generates a covariance matrix which can then be compared with the covariance matrix derived from empirical data. If the two matrices are consistent, then the structural equation model can be considered an acceptable explanation to determine these measurements' relationships.

This study examines or analyzes the relationship between the variables under study based on facts and data that have occurred and measures one variable's effect on the dependent variable. The variables studied comprised the independent variable and the dependent variable. The independent variables are family cohesion (X1) and parents' interpersonal communication (X2). Meanwhile, the dependent variable is smartphone addiction (X3) and emotional dysregulation in early childhood (Y). Based on the theoretical framework built-in Chapter II, research constellations can be planned as shown in Figure 1.

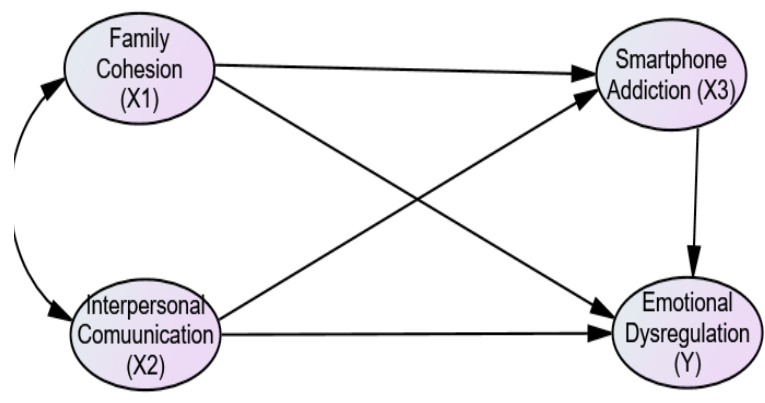

Figure 1. Constellation Research Model

The population of this study was all parents of kindergarten children in the city of Cirebon, Indonesia. It can access the population and distribution of kindergarten in Cirebon City through data from the database of the Ministry of Education of Indonesia, which can be seen in Table 1 and Table 2. 
Table 1. Kindergarten Institutions in Cirebon City Each District

\begin{tabular}{lcc}
\hline District & $\begin{array}{c}\text { Number of } \\
\text { Kindergarten } \\
\text { Institutions }\end{array}$ & $\begin{array}{c}\text { Total Number } \\
\text { of Parents }\end{array}$ \\
\hline Harjamukti & 30 & 930 \\
Lemahwungkuk & 10 & 256 \\
Pekalipan & 3 & 108 \\
Kesambi & 30 & 870 \\
Kejasan & 18 & 612 \\
Amount & 91 & 2,776 \\
\hline
\end{tabular}

Table 2. Selected Kindergarten Sample

\begin{tabular}{|c|c|c|}
\hline No & $\begin{array}{l}\text { Kindergarten } \\
\text { (Pseudoname) }\end{array}$ & $\begin{array}{l}\text { Number of Samples } \\
\text { for Each Institution }\end{array}$ \\
\hline 1 & $\mathrm{~A}$ & 62 \\
\hline 2 & $\mathrm{~B}$ & 51 \\
\hline 3 & $\mathrm{C}$ & 31 \\
\hline 4 & $\mathrm{D}$ & 14 \\
\hline 5 & $\mathrm{E}$ & 35 \\
\hline 6 & $\mathrm{~F}$ & 70 \\
\hline 7 & $\mathrm{G}$ & 30 \\
\hline \multirow[t]{2}{*}{8} & $\mathrm{H}$ & 45 \\
\hline & Amount & 338 \\
\hline
\end{tabular}

In connection with the data analysis technique using SEM (Structural Equation Model), strict research steps or procedures are set starting from the planning process to hypothesis testing. According to the opinion of Hair, Black, \& Anderson (2010), SEM modeling through seven stages; 1) Theory-based development; 2) development of flowcharts to show causality relationships; 3) conversion of flowcharts into a series of structural equations and measurement model specifications; 4) selection of input (input) matrices and estimation techniques for the model created; 5) assessing problem identification; 6) evaluating models; 7) interpreting and modifying the model.

Every variable that researchers do is by using standardized instruments. The instrument used is an instrument that has been well validated and has a good reliability value. Before the emotional development instrument (ITSEA), the interpersonal communication instrument (ICI), the family environment instrument (FES), and the smartphone addiction (SAS) instrument were used, the researcher first carried out a process of adaptation and modification. The process of modification and adaptation is a cross-cultural adaptation (Beaton, Bombardier, Guillemin, \& Ferraz, 2000). First, it carries the translation process or language translation of each instrument out. Then it is reviewed and adjusted to the cultural context, and the scale is adjusted to be used in other settings (Beaton et al., 2000).

The research questionnaire was compiled from the theory used. The research variable as a Latin construct is given an operational definition, then the indicators to be measured are determined. The indicators are then elaborated into statements or questions consistently. Sugiyono (2016) reminds that to determine the indicators of each variable being studied, and a deep insight is needed about the variables studied and the theories that support them. Using theory to construct instruments must be as careful as possible in order to get valid indicators.

\section{FINDINGS AND DISCUSSION Findings Demographic Profile of Children}

The children's age characteristics were arranged according to the frequency of children's ages, between 4,5 , and 6 years. The data is complete, as shown in Table 3.

Table 3. Child Age Distribution Table

\begin{tabular}{lccc}
\hline Child Age & Frequency & Percent & $\begin{array}{c}\text { Valid } \\
\text { Percent }\end{array}$ \\
\hline 4 & 75 & 23.540 & 22.190 \\
5 & 112 & 32.464 & 33.136 \\
6 & 151 & 43.768 & 44.675 \\
Total & 338 & 100.000 & \\
\hline
\end{tabular}

As seen in the Table 3, most respondents measured emotional dysregulation, and smartphone addiction was six years old, amounting to $43.76 \%$. While the rest by age four years $23 \%$ and five years $32 \%$.

Owning a smartphone is essential to seeing early childhood respondents' characteristics related to the smartphone addiction variable. The result is $67.83 \%$ or 234 children who do not have personal smartphones. It means that children only give loans to their children to play on smartphones. 
Related to the duration of smartphone use, the time spent using the smartphone shows that children who have an active duration of using their smartphone for over 5 hours are $55.65 \%$. This shows that the level of children's smartphone usage is relatively high.

From some explanations of the Table 3 , it can show children's characteristics as seen from the demographics and behavior of using children's smartphone addiction. These characteristics can be an initial condition for further analysis of family cohesion, interpersonal communication, and children's smartphone addiction to children's emotional dysregulation. The data is taken from the parents' answers describing the characteristics of the child. The total number of early childhood respondents studied was 338 .

\section{Data Analysis Results}

This study uses Structural Equation Modeling (SEM) analysis. The theoretical model described in the path diagram will be analyzed based on the data. Previously, several stages had been carried out in SEM, namely the stage of theory study, determination of instruments, and the next stage, namely data analysis. This data analysis was conducted to test the proposed research hypothesis. In more detail, it can be shown through the following stages.

\section{Form a Path Diagram}

From the study of the research theory, a path diagram model was formed, causality between latent variables shown in Figure 2.

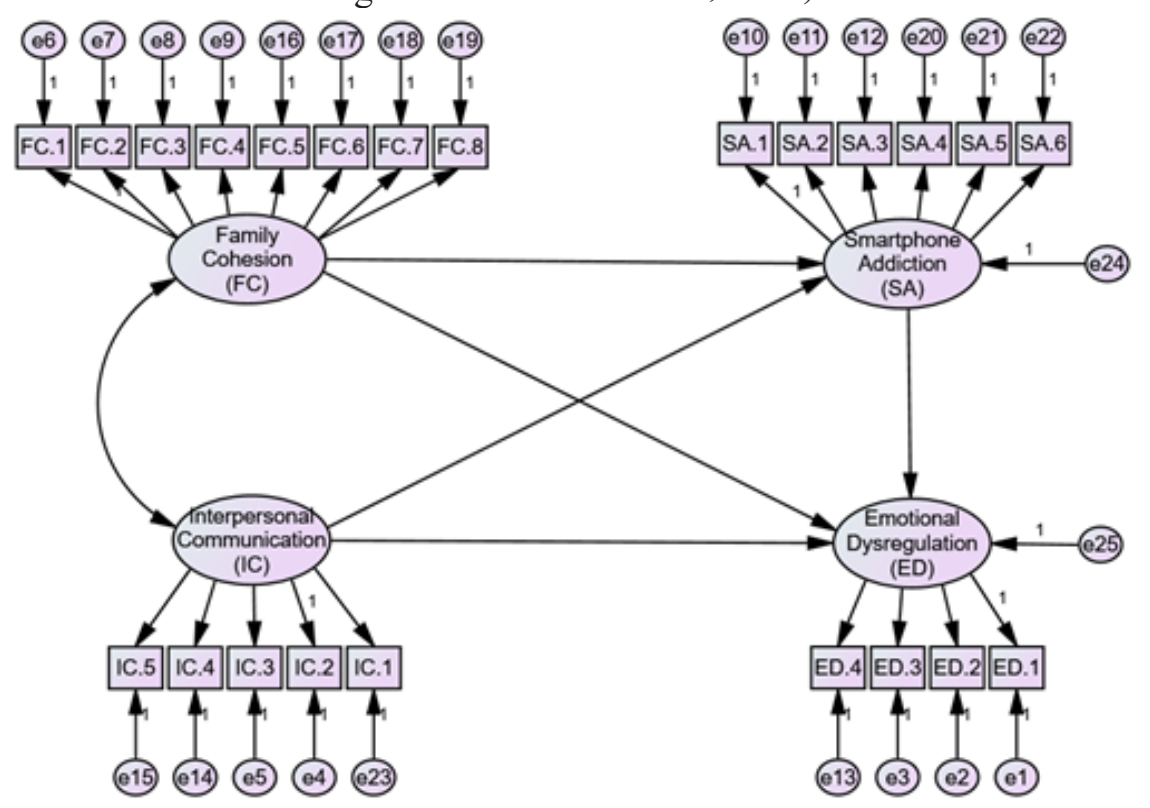

Figure 2. Path Diagram Model
Multicollinearity Assumption Test

The path diagram depicting the research model is converted into the SEM equation:

$$
\begin{aligned}
& E D=F C+I C+S A+\varepsilon \\
& S A=F C+I C+\varepsilon
\end{aligned}
$$

where $E D$ stands for emotional dysregulation, $F C$ is the family cohesion, $I C$ refers to the interpersonal communication, $S A$ represent the smartphone addiction, and $\varepsilon$ is the error. Or sub equations and structural equations:

$$
\begin{aligned}
& E D=\beta 1 F C+\beta 2 I C+\beta 3 S A+\delta 1 \\
& S A=\beta 2 F C+\beta 2 I C+\delta 1
\end{aligned}
$$

where $\beta 1$ is the regression weight and $\delta 1$ refers to the disturbance term.

\section{Confirmatory Factor Analysis}

Confirmatory Factor Analysis (CFA) is a modeling process in research to investigate the unidimensionality of indicators that explain a factor. This stage is testing orientation to get a fit variable model. The next stage is the structural measurement in the full analysis model.

CFA basic test for the goodness-of-fit test and the significance test of factor weights test for unidimensionality, explaining latent variables. Factor weight significance test aims to determine whether a variable can confirm other variables, done through lambda value or factor loading, and see regression weight. The required lambda value must reach more than or equal to .40 ; if the lambda value is lower than .40 , it is considered that the variable is not the same dimension as other variables to explain a latent variable (Hair et al., 2010).

doi:10.21831/cp.v40i2.34214 
Evaluation of the Overall Structural Model

After obtaining the exogenous variable model and the endogenous variable model that has been fit with empirical data, the measurement model, the next step is to conduct a structural model analysis by combining all variables in a structural model. The path diagram of the full structural equation model that will be estimated is as shown in Figure 3.

The full fit model in Figure 3 comprises four variables connected by a line with one arrow, and the variable family cohesion is connected to interpersonal communication with a line of 2 arrows. Endogenous variables for smartphone addiction and emotional dysregulation were given err var $(z)$, and variable dimensions were given err term $(z)$. The goodness-of-fit full model analysis has several fits (see Table 4). Several test parameters have been met, except the chi-square coefficient is still relatively high. Overall, the full structural model is fit according to empirical data. It should be understood that the fit model is based on goodness-of-fit testing, not always as a perfect model. Therefore it is still necessary to test construct-validity and construct reliability to determine the relationship between constructs, dimensions, and variable indicators.

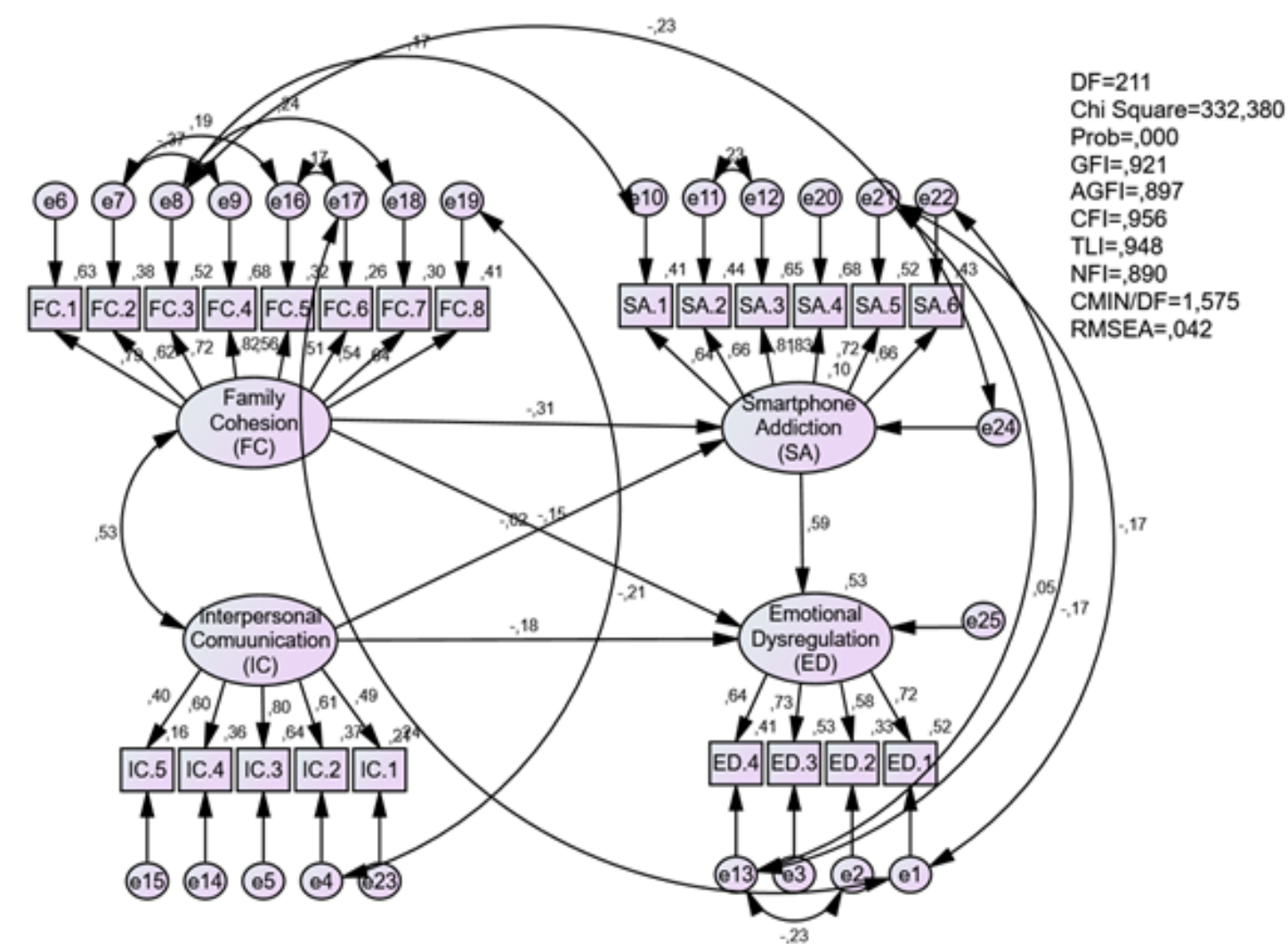

Figure 3. Model Fit

Table 4. Goodness of Fit

\begin{tabular}{lcrl}
\hline The Goodness of Fit Index & Cut-Off Value GOF Indices & Analysis Results & Conclusion \\
\hline Chi-Square & Chi-Square Expected to be small & 332.380 & Fit \\
Probability & $\geq .05$ & .000 & Marginal \\
RMSEA & $\leq .08$ & .042 & Fit \\
GFI & $\geq .90$ & .921 & Fit \\
AGFI & $\geq .90$ & .897 & Fit \\
CMIN/DF & $\leq 2.00$ & 1.575 & Fit \\
TLI & $\geq .95$ & .948 & Fit \\
CFI & $\geq .95$ & .956 & Fit \\
\hline
\end{tabular}


Hypothesis Test Analysis

The testing of the nine proposed hypotheses was carried out in three stages, namely (1) simultaneous hypothesis, and (2) partial hypothesis. The result of the hypothesis is presented in Table 5 .

Table 5. Hypothesis Test Results

\begin{tabular}{|c|c|c|c|c|c|}
\hline Variable & Variable & Estimate & $S E$. & $C R$. & $p$ \\
\hline FC & $\rightarrow \mathrm{ED}$ & -.142 & .066 & -2.156 & .031 \\
\hline IC & $\rightarrow \mathrm{ED}$ & -.282 & .117 & -2.417 & .016 \\
\hline SA & $\rightarrow \mathrm{ED}$ & .738 & .097 & 7.595 & $* * *$ \\
\hline $\mathrm{FC}$ & $\rightarrow \mathrm{SA}$ & -.229 & .059 & -3.879 & $* * *$ \\
\hline IC & $\rightarrow \mathrm{SA}$ & -.029 & .101 & -.292 & .771 \\
\hline
\end{tabular}

\section{Discussion}

\section{Family Cohesion Has a Negative Direct Effect} on Early Childhood Emotional Dysregulation

The first hypothesis analysis resulted in the finding that family cohesion has a positive direct effect on children's emotional dysregulation. It was evidenced by a $C . R$ value of $-2.156>1.96$ and a $p$ value of $.031<.05$, it can be concluded that Ho rejected, so H1. Based on these findings, it can be concluded that children's emotional dysregulation is directly affected by family cohesion. Children who are educated and cared for in family cohesion that prioritize positive and democratic growth will cause children to develop more positive emotions. Positive relationships between family members such as each family member provide commitment and support, open expression, overcome mutual conflicts, acceptance. It resulted in no dysregulation of children's emotions in terms of aggressiveness, children's anxiety, sensory sensitivity, and lack of focus.

The results are in line with some experts' opinion that according to Bandura, family cohesion is the environment that can affect early childhood development. According to (Hardani, 2017), it is strengthened that family cohesion is a positive relationship that occurs in the immediate environment and first for children in preparing children to enter the next social environment. It explains that early childhood has many experiences for the first time in the family environment. One such experience is learning about a variety of negative and positive emotions. One finding from his age explains that a child gets intense events or experiences depending on how the family interacts (Ackerman, 1958).

Kinship systems are characterized by (a) wholeness and regularity (i.e., the whole is greater than the number of its parts and has properties that cannot be understood only from the combined characteristics of each part), (b) hierarchical structure (i.e., the family comprises a subsystem which is a system), and (c) adaptive self-organization (i.e., the family, as an open living system, can adapt to change or challenges) (Cox \& Paley, 2003).

Thus, it can be concluded that the higher the family cohesion, the lower the emotional dysregulation of the child. Likewise, the lower family cohesion follows the higher emotional dysregulation of the child. From the above explanation, it can be concluded clearly that theoretically and empirically, family cohesion is proven to have a negative direct effect on emotional dysregulation in early childhood.

\section{Interpersonal Communication Has a Negative Direct Effect on Early Childhood Emotional Dysregulation}

The second hypothesis analysis results found that Interpersonal Communication has a negative direct effect on emotional dysregulation in Early Childhood. Evidenced by a C.R value of -2.417> 1.96 and a $p$ value of .016, it can be concluded that Ho is rejected, so H1. It shows that the higher the interpersonal communication of parents, the lower the emotional dysregulation of early childhood. Likewise, the lower the interpersonal communication, the higher the emotional dysregulation of the child.

These results are in line with previous studies. Whereas one goal of interpersonal communication in the family is to find the child's personal or personal character, empirical studies show that parents' interpersonal communication has less impact on children's emotions, especially on the child's personal or personal character. According to (Hartley, 1999), the variety of interpersonal communication skills, one of which is non-verbal, verbal, and reinforcement abilities and others from parents to children, directly affects children's emotional quality.

The next theory that supports the results is that of (Frydrychowicz, 2005) which explains that interpersonal communication matters in the psychological development between message recipients and message givers. As in this 
study, parents' interpersonal communication skills have a significant impact on children's emotional dysregulation. This is because of parents' interpersonal communication skills with other people or colleagues, which also provide similarities in parent's and children's interactions. Parents who can have verbal and non-verbal skills outside the home environment will impact the interpersonal relationship between parents and children. This also positively impacts the quality of children's emotional development, incredibly emotional dysregulation of early childhood.

From the explanation above, it can be concluded clearly that the higher the interpersonal communication of the parents, the lower the emotional dysregulation of the child, and vice versa, the lower the interpersonal communication of the parents, the higher the emotional dysregulation of early childhood. Theoretically and empirically, parental interpersonal communication is not proven to have a significant negative direct effect on emotional dysregulation in early childhood.

\section{Smartphone Addiction for Children Has a Positive Direct Effect on Early Childhood Emotional Dysregulation}

The third hypothesis analysis results result in the finding that Smartphone addiction directly affects children's emotional dysregulation. Evidenced by the value of C.R 7.595> 1.96 and a $p$ value of .000 , it can be concluded that Ho is rejected, so H1 is accepted. Based on these findings, it can be concluded that children's emotional dysregulation is directly affected by smartphone addiction in early childhood. As stated in the previous literature review, smartphone addiction differs from alcohol addiction. The addictions like this show excessive children's behavior in using smartphones. Children who often use smartphones will ignore their play environment to be more fun playing with smartphones than playing with their peers.

The results are in line with several experts' opinion that according to Young and Rogers, the aspect of Smartphone addiction comprises overthinking about smartphones, not being able to control oneself, worrying about not using a smartphone, and not knowing the time to use it. In line with what Griffiths expressed, such behavior is known as phubbing, which is the negative effect of Smartphone addiction (Essau, 2008). Then it is strengthened according to (Kwon, Kim, Cho, \& Yang, 2013), that the factors that can explain a child being affected by Smartphone addiction are based on changes in behavior, such as children's daily life, children's anxiety, and others. Meanwhile, according to (Imron, 2017) a child who is frequently in contact with gadgets can affect social-emotional development.

From the above explanation, it can be concluded that smartphone addiction directly affects emotional dysregulation in early childhood theoretically and empirically. Thus, the higher the child's smartphone addiction, the higher the emotional dysregulation of the child. Likewise, the lower the smartphone addiction, the lower the emotional dysregulation of the child. In line with research conducted by (Chiu, 2014) and (Chang, Chiu, Chen, Chiang, Miao, Chuang, \& Liu, 2019), who stated that smartphone addiction disorder is one reason for shifting stress an individual. This stress transfer occurs in the early childhood age range. It is proven that if early childhood is using a smartphone suddenly, the activity is interrupted by their parents. The child will experience a quite large tantrum; the child is less able to control himself. These symptoms show the child does not want to be disturbed by the pleasure caused by a smartphone.

Theoretical and empirical evidence also has similarities from that expressed by (Park \& Park, 2014), which states that smartphone addiction of early childhood impacts mental development such as emotional instability, depression, ADHD, anger, and lack of attention. Apart from impacting physical fatigue as decreased eye vision, smartphone addiction can also trigger other children's emotional disturbances.

From the explanation above, it can be concluded that the higher the child's smartphone addiction, the higher the emotional dysregulation of the child, and vice versa, the lower the smartphone addiction, the lower the emotional dysregulation of early childhood. Theoretically and empirically, parents' smartphone addiction has been shown to have a positive and direct significant effect on emotional dysregulation in early childhood. 


\section{Family Cohesion Has a Negative Direct Effect on Early Childhood Smartphone Addiction}

The fourth hypothesis analysis results result in the finding that family cohesion impacts smartphone addiction in early childhood. Evidenced by the value of $C R$ of $-3,879>1.96$ and the $p$ value of .000 , it can be concluded that Ho is rejected, so H1 is accepted. The level of Smartphone addiction in early childhood will be influenced by how family cohesion is formed. Family cohesion that shows positive values such as upholding mutual commitment and support, expressing feelings, handling conflicts in the family and others will impact the low level of children's smartphone addiction. Likewise, low family cohesion will impact the high level of smartphone addiction in early childhood.

Theoretically, the house's family cohesion can provide a sense of love, security, and adequate stimulation for children. Children raised in a family cohesion that respects each other and provides motivation and open affection can reduce the child's habit of spending time alone with no interaction with other family members. One result of this form of neglect of family members is that children will seek other forms of pleasure by using excessive smartphones.

Besides, family members who prioritize the value of recreation and organization in a controlled family will have the same effect. Family members who always routinely invite their children to vacation together and establish a controlled organizational system will reduce the level of children's smartphone use. This is because children realize that they will foster a sense of togetherness or bonding with other members by doing recreation together. It does not make children use smartphones excessively to look for children's momentary pleasure by playing games or watching on YouTube. Furthermore, research was conducted by (Kim \& Jahng, 2019).

The research results in Cirebon City found that family cohesion impacted children's smartphone addiction's low level. It can be seen that the level of cooperation, mutual responsibility, open communication, freedom, and family management is carried out very well. It is proven by the results of descriptive statistics that the level of family cohesion in Cirebon City is in the high category, which is $74.5 \%$. This shows that family cohesion, be it a small family or a family with a large enough number of members, has made the family a place to educate early childhood well and not use smartphones too often.

From the explanation above, it can be concluded clearly that theoretically and empirically, family cohesion is proven to influence children's Smartphone addiction.

\section{Interpersonal Communication Has no Direct Negative Effect on Early Childhood Smartphone Addiction}

The fifth hypothesis analysis results result in the finding that the level of Smartphone addiction in early childhood is not influenced by interpersonal communication. Evidenced by the value of $C R$ equal to $-.292 \leq 1.96$ and the $p$ value of .771 , it can be concluded that Ho is accepted, so H1 is rejected. These results show that interpersonal communication does not affect early childhood smartphone addiction. The results are certainly different from previous studies, which explain that interpersonal communication affects smartphone addiction.

The results differed from some experts such as (De Vito 1994), who said that influencing influence is a process that is psychological and still provides opportunities for the formation of togetherness. This is reinforced by the view of (Greene \& Burleson, 2003) that interpersonal communication is dyadic communication, which occurs between two individuals who give and receive information so that a relationship can create meaning. The experts 'explanation shows that parents' interpersonal communication skills cannot limit children's habits in using smartphone addiction.

The same thing with other dimensions of interpersonal communication, such as the ability to express one's thoughts and ideas and constructively deal with emotions, does not have a significant correlation with children's behavior using devices or smartphones. Even though the interpersonal communication skills of parents in Cirebon are in the high category, this ability does not show any correlation with the consequences of children being addicted to smartphones such as withdrawal, virtual world orientation relationships are more fun than the real world of children and the attitude of parents who always feel guilty, when the child uses the smartphone for too long. 
It can be concluded that the form of interpersonal communication skills as verbal and non-verbal language cannot an excuse for children not using smartphones; early childhood will continue to use smartphones even though parents have fairly good interpersonal communication skills. In general, the quality of interpersonal communication, such as a sense of openness, empathy, and mutual support, cannot guarantee that early childhood will follow their parents' orders not to use smartphones excessively.

The research results in Cirebon City found that the level of interpersonal communication of parents in the city of Cirebon was in the medium to high category. This shows that parents in Cirebon City terms of communication competence, self-concept in communicating, and emotional management when communicating with other people or their children are in the high category. Such as being a good listener, the ability to express one's thoughts and ideas clearly, the ability to deal with emotions in constructive ways, and the desire to communicate with others freely and frankly. This ability does not directly impact the level of Smartphone addiction in early childhood because parents can become a person who is capable of communicating skills, not in the measure of a parent's assertiveness to his child.

From the explanation above, it can be concluded clearly that theoretically and empirically, interpersonal communication is not proven to affect smartphone addiction in early childhood.

\section{CONCLUSION}

Based on each hypothesis's overall conclusion, the overall role of Smartphone addiction has a role or becomes an important intervening variable between family cohesion and interpersonal communication on children's emotional dysregulation. Children's emotional dysregulation will be high if family cohesion and communication are low, coupled with the presence of high smartphone addiction, it will undoubtedly exacerbate children's emotional dysregulation. On the other hand, emotional dysregulation will be low if family cohesion and interpersonal communication are high, and low smartphone addiction levels offset this. Another thing happens if under certain conditions there is family cohesion and high interpersonal communication. However, it is mediated or the presence of high smartphone addiction in children, then this will also have a high impact on the problem of children's emotional dysregulation. Conversely, if we find low family cohesion and interpersonal communication, and in the mediation or presence of common smartphone addiction, emotional dysregulation will still affect. However, the effect is not as significant as compared to high smartphone addiction.

\section{REFERENCES}

Achenbach, T. M., Edelbrock, C., \& Howell, C. T. (1987). Empirically based assessment of the behavioral/emotional problems of 2-and 3-year-old children. Journal of Abnormal Child Psychology, 15(4), 629-650. $\quad$ https://doi.org/10.1007/ BF00917246.

Ackerman, N. W. (1958). The psychodynamics of family life: Diagnosis and treatment of family relationships. New York, NY: Basic Books.

Beaton, D. E., Bombardier, C., Guillemin, F., \& Ferraz, M. B. (2000). Guidelines for the process of cross-cultural adaptation of self-report measures. Spine, 25(24), 31863191. https://doi.org/10.1097/00007632200012150-00014.

Bronson, M. B. (2001). Self-regulation in early childhood: Nature and nurture. New York, NY: Guilford Press.

Calkins, S. D., \& Dedmon, S. E. (2000). Physiological and behavioral regulation in two-year-old children with aggressive/destructive behavior problems. Journal of Abnormal Child Psychology, 28(2), 103-118. https://doi. org/10.1023/a:1005112912906.

Chang, F. C., Chiu, C. H., Chen, P. H., Chiang, J. T., Miao, N. F., Chuang, H. Y., \& Liu, S. (2019). Children's use of mobile devices, smartphone addiction and parental mediation in Taiwan. Computers in Human Behavior, 93, 25-32. https://doi. org/10.1016/j.chb.2018.11.048. 
Chiu, S.-I. I. (2014). The relationship between life stress and smartphone addiction on Taiwanese university students: A mediation model of learning self-efficacy and social self-efficacy. Computers in Human Behavior, 34, 49-57. https://doi. org/10.1016/j.chb.2014.01.024.

Coll, C. G., Kagan, J., \& Reznick, J. S. (1984). Behavioral inhibition in young children. Child Development, 55(3), 1005-1019. https://doi.org/10.2307/1130152.

Cox, M. J., \& Paley, B. (2003). Understanding families as systems. Current Directions in Psychological Science, 12(5), 193-196. https://doi.org/10.1111/1467-8721.01259.

De Vito, J. (1994). Human communication: The basic course. Boston, MA: Pearson Education.

Denham, S. A., Bassett, H. H., \& Wyatt, T. M. (2010). Gender differences in the socialization of preschoolers' emotional competence. New Directions for Child and Adolescent Development, 2010(128), 29-49. https://doi.org/10.1002/cd.267.

Essau, C. A. (2008). Adolescent addiction: Epidemiology, assessment, and treatment $\left(1^{\text {st }}\right.$ ed). London, UK: Elsevier.

Frydrychowicz, S. (2005). The influence of interpersonal communication on human development. Psychology of Language and Communication, 9(2), 69-82. http:// www.plc.psychologia.pl/plc/plc/contents/ fulltext/09-2 5.pdf.

Greene, J. O., \& Burleson, B. R. (Eds.). (2003). Handbook of communication and social interaction skills. In Communication. New York, NY: Routledge. https://doi. org/10.4324/9781410607133.

Gutiérrez, J. D. S., de Fonseca, F. R., \& Rubio, G. (2016). Cell-phone addiction: A review. Frontiers in Psychiatry, 7, 1-15. https:// doi.org/10.3389/fpsyt.2016.00175.

Hair, J. F., Black, W. C., E, B. J. B., \& Anderson, R. (2010). Multivariate data analysis $\left(4^{\text {th }}\right.$ ed). New Jersey, NJ: Pearson Prentice
Hall.

Hardani, R. (2017). Pengaruh kelekatan anak dengan orang tua, guru, teman dan kontril diri terhadap perilaku pornografi anak SMP. [The influence of children's attachment to parents, teachers, friends and self-disclosure on pornographic behavior of junior high school children]. (Master Thesis, Institut Pertanian Bogor). $\quad$ http://repository.ipb.ac.id/ handle/123456789/87433.

Hartley, P. (1999). Interpersonal communication. London, UK: Routledge.

Havighurst, S. S., Wilson, K. R., Harley, A. E., Kehoe, C., Efron, D., \& Prior, M. R. (2013). "Tuning into Kids": Reducing young children's behavior problems using an emotion coaching parenting program. Child Psychiatry \& Human Development, 44(2), 247-264. https://doi.org/10.1007/ s10578-012-0322-1.

Hidayati, F., Kaloeti, D. V. S., \& Karyono, K. (2011). Peran ayah dalam pengasuhan anak. [The father's role in child care]. Jurnal Psikologi, 9(1), 1-10. https:// ejournal.undip.ac.id/index.php/psikologi/ article/view/2841/2525.

Imron, R. (2017). Hubungan penggunaan gadget dengan perkembangan sosial dan emosional anak prasekolah di Kab. Lampung Selatan. [The relationship between the use of gadgets and the social and emotional development of preschool children in Lampung Selatan Regency]. Jurnal Keperawatan, 13(2), 148-154. https://doi.org/10.26630/jkep.v13i2.922.

Joormann, J., \& Gotlib, I. H. (2010). Emotion regulation in depression: Relation to cognitive inhibition. Cognition and Emotion, 24(2), 281-298. https://doi. org/10.1080/02699930903407948.

Joormann, J., \& Quinn, M. E. (2014). Cognitive processes and emotion regulation in depression. Depression and Anxiety, 31(4), 308-315. https://doi.org/10.1002/ da.22264. 
Kildare, C. A., \& Middlemiss, W. (2017). Impact of parents mobile device use on parent-child interaction: A literature review. Computers in Human Behavior, 75, 579-593. https://doi.org/10.1016/j. chb.2017.06.003.

Kim, D., \& Jahng, K. E. (2019). Children's self-esteem and problematic smartphone use: The moderating effect of family rituals. Journal of Child and Family Studies, 28(12), 3446-3454. https://doi. org/10.1007/s10826-019-01526-1.

Kwon, M., Kim, D. J., Cho, H., \& Yang, S. (2013). The smartphone addiction scale: Development and validation of a short version for adolescents. PLOS ONE, 8(12), 1-7. $\quad$ https://doi.org/10.1371/journal. pone. 0083558 .

Macklem, G. L. (2007). Practitioner's guide to emotion regulation in school-aged children. New York, NY: Springer Science \& Business Media.

Miller, A. L., Gouley, K. K., Seifer, R., Dickstein, S., \& Shields, A. (2004). Emotions and behaviors in the head start classroom: Associations among observed dysregulation, social competence, and preschool adjustment. Early Education and Development, 15(2), 147-166. https:// doi.org/10.1207/s15566935eed1502_2.

Olatunji, B. O., Forsyth, J. P., \& Feldner, M. T. (2007). Implications of emotion regulation for the shift from normative fear-relevant learning to anxietyrelated psychopathology. American Psychologist, 62(3), 257-259. https://doi. org/10.1037/0003-066X.62.3.257.

Papalia, D. E., Feldman, R. D., Martorell, G.,
Morán, E. B., Herrera, M. V., Salinas, M. E. O., \& Dávila, J. F. (2012). Desarrollo humano. México, DF: McGraw Hill.

Park, C., \& Park, Y. R. (2014). The conceptual model on smart phone addiction among early childhood. International Journal of Social Science and Humanity, 4(2), 147150. https://doi.org/10.7763/IJSSH.2014. $\underline{\mathrm{V} 4.336 .}$

Pond, R. S., Kashdan, T. B., DeWall, C. N., Savostyanova, A., Lambert, N. M., \& Fincham, F. D. (2012). Emotion differentiation moderates aggressive tendencies in angry people: A daily diary analysis. Emotion, 12(2), 326-337. https:// doi.org/10.1037/a0025762.

Robins, L. N., \& Rutter, M. (1990). Straight and devious pathways from childhood to adulthood. Cambridge: Cambridge University Press.

Rubinsztein, D. C., Gestwicki, J. E., Murphy, L. O., \& Klionsky, D. J. (2007). Potential therapeutic applications of autophagy. Nature Reviews Drug Discovery, 6(4), 304-312. https://10.1038/nrd2272.

Sugiyono. (2016). Statistika untuk penelitian. [Statistics for research]. Bandung, Indonesia: Alfabeta.

Warisyah, Y. (2015). Pentingnya "pendampingan dialogis" orang tua dalam penggunaan gadget pada anak usia dini. [The importance of "dialogical assistance" of parents in the use of gadgets in early childhood]. Seminar Nasional Pendidikan 2015, Inovasi Pembelajaran untuk Pendidikan Berkemajuan BUKU 1, 130138. http://seminar.umpo.ac.id/index.php/ semnasdik2015/article/view/212. 